\title{
Potential production of Aspidosperma cylindrocarpon seedlings viarescue seedlings
}

\author{
Nathália Ferreira e Silva ${ }^{1^{*}}$ Israel Marinho Pereira ${ }^{1}$ Michele Aparecida Pereira da Silva ${ }^{1}$ \\ Miranda Titon ${ }^{1}$ Marcio Leles Romarco de Oliveira ${ }^{1}$ Luana Cristielle Araújo $^{1}$ Leandro Carlos $^{1}$
}

${ }^{1}$ Universidade Federal dos Vales do Jequitinhonha e Mucuri (UFVJM), Campus JK, Rodovia MGT 367, Km 583, n 5000, Alto Jacuba, 39100-000, Diamantina, MG, Brasil. E-mail: imarinhopereira@gmail.com. "Corresponding author.

ABSTRACT: Translocation of rare populations is regarded as the last resort for the conservation of species whose habitat destruction is imminent. The objective of the present study was to evaluate the effect of two height classes and three leaf reduction intensities on growth and increases in height, stem diameter, survival, and new leaf production in seedlings of Aspidosperma cylindrocarpon (peroba) obtained via rescue seedlings in a remnant of tropical semi deciduous forest. We recovered 240 individuals that were divided into two height classes (Class I-5 to $15 \mathrm{~cm}$ and Class II-20 to $35 \mathrm{~cm}$ ) and subjected to three leaf reduction intensities $(0 \%, 50 \%$, and $100 \%)$, which were then transported to a shade house with $50 \%$ light reduction. Measurements of height, stem diameter, and new leaf production were collected 8 times at 0, 15, 60, 75, 90, 105, 120, and 135 days, and survival rate was measured at day 135 . The average survival rate was $82.9 \%$; $77.5 \%$ for one Class I (5-15cm) and $88.3 \%$ for Class II (20-35cm). Higher seedling growth was observed for the $0 \%$ leaf reduction treatment in both height classes. The leaves insertion were greater in the $100 \%$ cuts, with a decrease observed over time. It is advisable to restore A. cylindrocarpon seedlings in two height classes owing to the high survival rate, leaf appearance, and growth reported in the present study. The no-leaf reduction treatment $(0 \%)$ is the most viable alternative for the production of A. cylindrocarpon seedlings, via rescue seedlings.

Key words: peroba, leaf reduction, height class.

Potencial de produção de mudas de Aspidosperma cylindrocarpon via resgate de plântulas

RESUMO: As translocações de populações raras são consideradas como o último recurso para conservação de espécies, cuja destruição do habitat é iminente. O objetivo deste trabalho foi avaliar o efeito de duas classes de altura e três intensidades de redução foliar no crescimento, incremento periódico, sobrevivência e inserção de folhas em mudas de Aspidosperma cylindrocarpon (peroba) obtidas via resgate de plântulas em um remanescente de Floresta Estacional Semidecídua. Foram resgatados 240 individuos, os quais foram divididos em duas classes de altura (Classe I-5 a $15 \mathrm{~cm}$ e Classe II20 a 35cm), submetidos a três intensidades de redução foliar (0\%, 50\% e 100\%) e em seguida, transportados para casa de sombra com $50 \%$ de redução de luminosidade. As medições de altura, diâmetro e emissão de novas folhas foram realizadas em oito tempos (0, 15, 60, 75, 90, 105, 120 e 135 dias), e a sobrevivência aos 135 dias. A taxa média de sobrevivência foi de 82,9\%, sendo 77,5\% para a classe de 5-15cm e 88,3\% para classe de 20-35cm. $O$ maior crescimento das mudas ocorreu para a redução de $0 \%$, para ambas as classes. A inserção de folhas foi maior nas reduções de $100 \%$, observandose diminuição ao longo do tempo. Portanto, é aconselhável resgatar mudas de peroba nas duas classes de altura, sem necessidade de redução foliar. Palavras-chave: peroba, redução foliar, classe de altura.

\section{INTRODUCTION}

Habitat loss is a major threat to biodiversity worldwide (FALK et al., 1996). Increasing deforestation and the formation of degraded areas in tropical regions require urgent interventions to preserve biodiversity (LAMB et al., 2005). Therefore, the replacement of vegetation to a similar condition to what was present before the disturbance is frequently necessary in a reclamation system and an alternative to problems associated with individual flora rescue (GOOD et al., 1999).

Translocation of rare populations is regarded as the last option for the conservation of species whose habitat destruction is imminent, or when an environmental licensing is authorising vegetation removal, with this possibly being the only means of preserving these rare populations (WENDELBERGER et al., 2008). One of the species used in translocation programs is Aspidosperma cylindrocarpon Müll. Arg. (peroba), classified as a late secondary species and belonging to the family Apocynaceae; it is a native semi deciduous forest species and has been classified as endangered (CARVALHO, 1994). This particular species is utilized in such programs because of its potential for ecological restoration of degraded areas.

There are currently no scientific studies on rescue seedlings for $A$. cylindrocarpon species. The few studies that are available in the literature regarding young individual transplant tropical species report the need to achieve cuts in leaves of $50 \%$ for each individual. This process helps to manage success of transplanting, owing to reduction of water stress, and 
facilitating visualisation the production of new leaves in the plant. To avoid water loss through transpiration, XAVIER et al. (2009) recommended a reduction in the leaf lamina by $50 \%$, which is a percentage that is common in proportional clonal production of root cuttings of Eucalyptus in Brazil. The leaf reduction aimed to avoid the 'umbrella' phenomenon, which can potentially affect irrigation efficiency and prevent excessive sweating (SANTANA et al., 2010).

The objectives of the present study were to obtain information on the effectiveness of the $A$. cylindrocarpon seedling rescue technique, evaluating the effect of two height classes and three leaf reduction intensities on growth, survival, and new leaf production in nursery conditions, with the future aim to use these findings in restoration projects of gravel pits.

\section{MATERIALS AND METHODS}

Two hundred and forty A. cylindrocarpon seedlings were randomly collected from a transitional remnant of tropical semi deciduous forest and the cerrado, in the Mendanha district, Diamantina-MG, Brazil, in December 2010. From these seedlings, 120 were classified as Class I, i.e. 5 to $15 \mathrm{~cm}$ high and the other 120 were classified as Class II, i.e. 20 to $35 \mathrm{~cm}$ high.

The experimental material was manually collected from the radicial region, packed in containers with water, and taken to the Integrated Center of Forest Species Propagation (CIPEF), Department of Forestry of UFVJM in Diamantina, where the experiment was carried out immediately after collection. The CIPEF is located approximately $1390 \mathrm{~m}$ above sea level, and the average annual temperature and rainfall are $18.1^{\circ} \mathrm{C}$ and $1404 \mathrm{~mm}$, respectively. Seedlings were transplanted into polyethylene bags $(30 \times 20 \mathrm{~cm})$ filled with substrate composed of $70 \%$ subsoil (Neossolo), 30\% Bioplant ${ }^{\circledR}$, and $7 \mathrm{~g} \mathrm{~L}^{-1}$ Osmocote $^{\circledR}$ in the ratio (NPK) of 9:15:12. Seedlings were maintained in a shade house with shade cover enabling a 50\% reduction in light and sprinkler irrigation with a flow rate of $85 \mathrm{~L} \mathrm{~h}^{-1}$. After 110 days, the seedlings had undergone the process of rustification in the open and the sprinkler irrigation was increased to a flow rate of $200 \mathrm{~L} \mathrm{~h}^{-1}$, which continued until the final evaluation. Any excessively large or bent roots were pruned when leaked transplant recipient. Weed control was manually performed when necessary.

Four variables were evaluated throughout the experiment, including growth and the increase in height $(\mathrm{cm})$, stem diameter $(\mathrm{mm})$, survival of seedlings and production of leaves, in order to identify the responses of $A$. cylindrocarpon seedlings after the intervention of the different treatments.
For the first two variables (i.e. growth and stem diameter), a completely randomized design was used with four replications, in a split plot $2 \times 3 \times 8$. In the main section, the effect of two size classes was studied (Class I and Class II); in the first subplot, 3 leaf reduction intensities $(0 \%$ - no leaf reduction, $50 \%-50 \%$ reduction in all leaves, and $100 \%$ - total removal of leaves) were studied; and in the second subplot, 8 time periods $(0,15,60,75,90,105,120$, and 135 days) were studied. Each experimental unit consisted of 10 seedlings. Evaluation of the survival rate was conducted on day 135 for treatments related to the size of Class I and Class II and leaf reduction treatments $(0 \%, 50 \%$, and $100 \%)$; therefore, a $2 \times 3$ factorial analysis. Production of leaves was evaluated from the percentage of individuals who produced new leaves throughout the time periods analyzed, i.e. a regression analysis versus time, for each combination (classes $\mathrm{x}$ reduction in intensity), totalling six equations.

The total height was defined as the distance from the substrate to the insertion level of the last apical meristem and was measured with a ruler graduated in centimetres and the stem diameter was measured with a digital calliper graduated in millimetres. Survival rate $(\%)$ was evaluated from the number of plants killed at day 135 , which was based on the absence of dried leaves and stalks. The periodic increment (IP) of height and stem diameter was obtained by the difference of successive measurements from the initial measurement IP $=\overline{\mathrm{X}}_{\mathrm{t}+1}-\overline{\mathrm{X}}_{1}$, where in $\overline{\mathrm{X}}$ is the average heights and diameters.

Data were subjected to analysis of variance and, if necessary, Tukey's test at 5\% probability for the qualitative treatments was performed. For the variables of overall height, stem diameter, and production of periodic incremental leaves over time, a regression analysis was performed to represent the trend of the variable results. Statistical analyses were performed using Statistica 10.0 (STATSOFT, 2010).

\section{RESULTS AND DISCUSSION}

For height growth, a statistically significant difference was obtained for the time factor and interaction of height class $\times$ leaf reductions. While the stem diameter showed significant differences $(\mathrm{P}<0.05)$, this was only in the variation related to height class and time (Table 1). This significant interaction suggested that the height is more responsive to variations in the size class and leaf reduction in seedlings, although both biometric variables evaluated responded positively to time, resulting in an increase after 135 days. 
Table 1 - Growth analysis of variance summary and increment in height and stem diameter of mahogany seedlings over the 135 days after the rescue.

\begin{tabular}{|c|c|c|c|c|}
\hline & \multirow[b]{2}{*}{ Height $(\mathrm{cm})$} & \multirow[b]{2}{*}{ Stem diameter $(\mathrm{mm})$} & \multicolumn{2}{|c|}{ 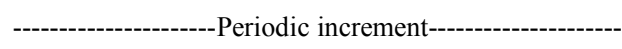 } \\
\hline \multirow{2}{*}{ Source of variation } & & & Height $(\mathrm{cm})$ & Stem diameter $(\mathrm{mm})$ \\
\hline & QM & $\mathrm{QM}$ & $\mathrm{QM}$ & $\mathrm{QM}$ \\
\hline Classes (c) & $103184.6^{*}$ & $2481.6^{*}$ & $0.3884^{\mathrm{ns}}$ & $1.7492^{\mathrm{ns}}$ \\
\hline Residue a & 67.4 & 4.6 & 1.8016 & 1.3910 \\
\hline $\mathrm{CVa}_{\exp }(\%)$ & 44.4 & 51.9 & 153.53 & 277.48 \\
\hline Reductions (r) & $386.1^{\mathrm{ns}}$ & $15.6^{\mathrm{ns}}$ & $3.5050^{\mathrm{ns}}$ & $1.2696^{\mathrm{ns}}$ \\
\hline $\mathrm{c} \times \mathrm{r}$ & $505.7^{*}$ & $10.8^{\text {ns }}$ & $1.5157^{\mathrm{ns}}$ & $1.8070^{*}$ \\
\hline Residue b & 100.9 & 8.7 & 4.5339 & 0.4188 \\
\hline $\mathrm{CVb}_{\exp }(\%)$ & 54.3 & 78.8 & 253.79 & 152.27 \\
\hline Time(t) & $69.0^{*}$ & $9.8^{*}$ & $6.0146^{*}$ & $0.8742^{*}$ \\
\hline $\mathrm{txc}$ & $8.0^{\mathrm{ns}}$ & $0.3^{\text {ns }}$ & $1.0240^{*}$ & $0.1352^{*}$ \\
\hline $\mathrm{t} \times \mathrm{r}$ & $1.8^{\text {ns }}$ & $0.6^{\mathrm{ns}}$ & $0.2302^{\text {ns }}$ & $0.0863^{*}$ \\
\hline $\mathrm{t} x \mathrm{c} \times \mathrm{r}$ & $0.6^{\mathrm{ns}}$ & $0.2^{\mathrm{ns}}$ & $0.0573^{\mathrm{ns}}$ & $0.0257^{\mathrm{ns}}$ \\
\hline Residue c & 69.0 & 9.8 & 0.1533 & 0.0355 \\
\hline $\mathrm{CVc}_{\exp }(\%)$ & 16.8 & 24.5 & 44.79 & 44.39 \\
\hline
\end{tabular}

${ }^{\mathrm{ns}}$ No significant. *Significant at 5\% de probability by test F. QM, mean square; CV, experimental coefficient of variation.

For the periodic increment in height, significant differences for the interaction of height class $\times$ time were observed, indicating an increase in diameter, and significant differences were also observed for height class $\times$ leaf reduction, time $\times$ height class and time $\mathrm{x}$ leaf reduction.

For growth data in height, no significant difference $(\mathrm{P}>0.05)$ was observed in Class I for any of the leaf reduction intensities; although, the $0 \%$ treatment was found to lead to greater height than the other treatments. For Class II, $0 \%$ and $50 \%$ reductions were not significantly different and were greater than the $100 \%$ reduction relating to the seedlings height. Therefore, based on the results for these variables and for the stem diameter, which was not affected by the different levels of leaf reduction, it is recommended for the species studied that leaf reduction should not be performed. These results are similar to those reported by SANTANA et al. (2010) who studied mini-cuttings of eight hybrids of Eucalyptus urophylla at four reduced leaf levels $(0 \%, 25 \%, 50 \%$, and $75 \%)$, and showed that for the time variables studied, any leaf reduction level could be adopted.

Table 2 shows the averages of the periodic increase in stem diameter for the interaction between leaf reduction $\times$ height class and their statistical significance. There was no significant difference $(\mathrm{P}>0.05)$ between the two classes and $50 \%$ and $100 \%$ reductions; however, a significant difference was observed for the $0 \%$ reduction treatment. In Class I, there was no significant difference between the three leaf reduction intensities, contrasting with Class II, where significant differences were reported for the $0 \%$ and $100 \%$ reductions, but not for the $50 \%$ reduction treatment. Despite the $0 \%$ and 50\% leaf reduction treatments being statistically equal, the increase in the Class II treatment, which was not reduced (0.826), was greater than the Class I treatment. Stem diameter is an important variable to assess the survival and growth of seedlings, as it is indicative of their quality (CARNEIRO, 1995; SOUZA et al., 2006).

Thus, according to the results, the treatment that did not suffer leaf reductions $(0 \%)$ showed greater increases in stem diameter than the other treatments, which is confirmed by the adjustment made to the quadratic model for interaction time $\times$ leaf reduction (Figure 1A). This smaller incremental growth in

Table 2 - Mean results of the periodic increment in diameter of the peroba seedlings depending on the three leaf reduction and intensities of the two size classes (1).

\begin{tabular}{|c|c|c|c|c|c|c|}
\hline \multirow{3}{*}{$\begin{array}{l}\text { Classes } \\
(\mathrm{cm})\end{array}$} & \multicolumn{6}{|c|}{ 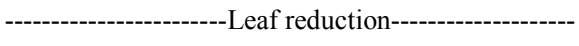 } \\
\hline & \multicolumn{2}{|c|}{$0 \%$} & \multicolumn{2}{|c|}{$50 \%$} & \multicolumn{2}{|c|}{$100 \%$} \\
\hline & ------- & ----יני & -------. & m-- & -------. & ------- \\
\hline $5-15$ & 0.318 & $\mathrm{aB}$ & 0.308 & $\mathrm{aA}$ & 0.378 & $\mathrm{aA}$ \\
\hline $20-35$ & 0.826 & $\mathrm{aA}$ & 0.452 & $\mathrm{abA}$ & 0.259 & $\mathrm{bA}$ \\
\hline
\end{tabular}

${ }^{(1)}$ Means followed by the same letter on the line and capitalized in the column do not differ statistically by Tukey test at $5 \%$ probability. 


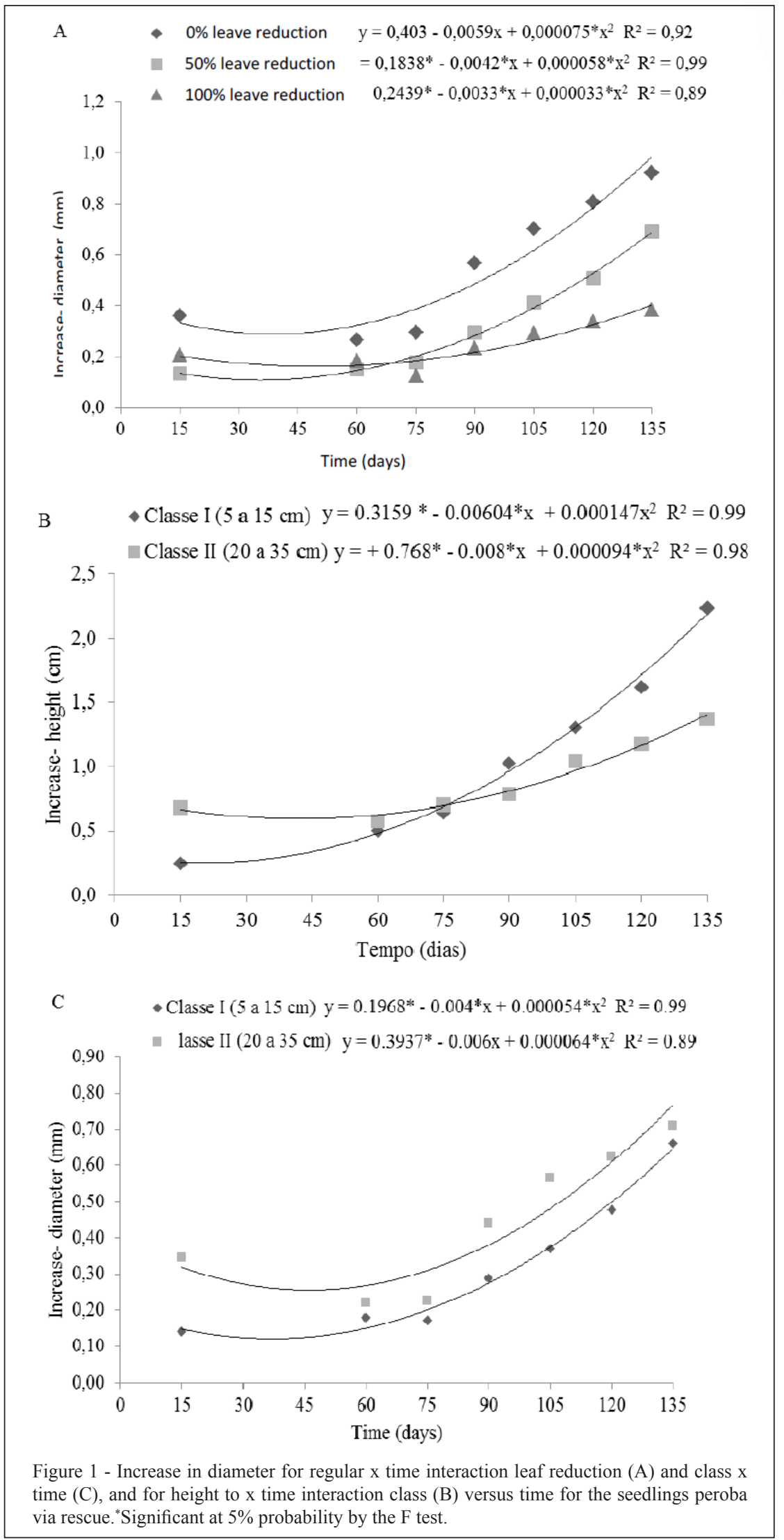

Ciência Rural, v.47, n.5, 2017. 
stem diameter for treatments that underwent leaf reductions can be explained by a potentially lower photosynthetic activity in these plants and their lower resilience (LIMA et al., 2008).

With respect to height class $\times$ time interactions, there was, for the time variable, within 60 days the largest height increase was for Class II, equalling Class I after 75 days. After that, Class I seedlings had greater increases in height than Class II seedlings (Figure 1B). For the stem diameter variable, the curves are similar; however, Class II plants presented greater incremental gains (Figure 1C). Therefore, because Class II consists of more developed plants, their secondary growth was greater, as was their increase in stem diameter. This is in contrast to Class I plants, where there is a predominance of primary growth in juvenile material, implying that the growth effect on height is greater, possibly owing to the high auxin/ cytokinin ratio, which are important plant hormones for stem elongation and cell expansion, respectively (RAVEN et al., 2007).

The survival rate of the 240 seedlings recovered was $82.9 \%$; with $77.5 \%$ for Class I and $88.3 \%$ for Class II. Values of the survival rates of seedlings obtained in the present study were higher than the rates reported in other studies of the remaining tropical semi deciduous forest (VIDAL, 2008; CALEGARI et al., 2011). This can be explained by the differences in the methodologies used, with previous authors rescuing all seedlings, regardless of species, which were within the parameters evaluated in the collection area, whereas in the present study only one species was rescued.

Statistical significance was observed for the interaction of height class size reduction $\times$ leaf characteristic survival. No statistical difference was observed between the two height classes for both the $0 \%$ and $50 \%$ reductions (Table 3 ). In contrast, VIANI \& RODRIGUES (2007), in a study of several native species of young rescue plants arising from a fragmented forest, found higher survival for the height class between 11 and $20 \mathrm{~cm}$.

The $0 \%$ and $100 \%$ leaf reductions were statistically different, but similar for the $50 \%$ reduction treatment in Class I, thus verifying that the treatment with improved survival has did not undergo leaf reduction. For Class II, there was no statistical difference between the three leaf reduction intensities. The beneficial effects of the presence of leaves have been reported by HARTMANN et al. (2002), who showed that for many species the presence of leaves or parts thereof is a prerequisite for the production of auxins and cofactors, which are promoter sources for
Table 3 - Average results of the survival of mahogany seedlings depending on the three leaf reduction intensities and two size classes (1).

\begin{tabular}{|c|c|c|c|c|c|}
\hline \multirow{3}{*}{$\begin{array}{l}\text { Classes } \\
(\mathrm{cm})\end{array}$} & \multicolumn{5}{|c|}{--------------------Leaf reduction------------------ } \\
\hline & \multicolumn{2}{|c|}{$0 \%$} & $50 \%$ & \multicolumn{2}{|c|}{$100 \%$} \\
\hline & --------. & $-\cdots$ & -----------\%---- & 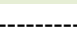 & ------.- \\
\hline $5-15$ & 87.50 & $\mathrm{aA}$ & 80.00 & 65.00 & $\mathrm{bB}$ \\
\hline $20-35$ & 77.50 & $\mathrm{aA}$ & 95.00 & 92.50 & $\mathrm{aA}$ \\
\hline
\end{tabular}

${ }^{(1)}$ Means followed by the same letter on the line and capitalized in the column do not differ statistically by Tukey test at 5\% probability.

rooting, and move through the plant, from the apex to the base, favouring root formation.

Seedlings of Class I had more leaves produced over time for the three leaf reduction intensities than Class II seedlings with the same reduction intensities. However, this variable showed higher production in the $100 \%$ leaf reduction for the two height classes, which can be explained by a more pronounced budding capacity intrinsic to the species. Therefore, entirely pruning the seedlings of $A$. cylindrocarpon inhibits apical dominance (typically caused by the higher concentration of auxin) (CLINE, 1994).

The percentage of surviving individuals who produced new leaves was increased in the treatment that suffered no reduction in leaves of Class I (T1) and for treatments with $50 \%$ leaf reduction in both height classes (T2 and T5). Unlike treatments that have all their leaves removed (T3 and T6) and did not suffer leaf reduction Class II (T4) in which a quadratic effect was seen initially showing increased leaf emission, however, over time, a negative trend was observed. This result was possibly caused by a lack of vigour of the leaves and/or insufficient photosynthetic activity to meet the energy demand of the roots and other organs of the plant.

Thus, individuals in both height classes and those that did not suffer leaf reduction responded positively to translocation, by periodic incremental growth, survival, or production of new leaves. The benefits of non-leaf reduction include reducing the time and cost involved in the production of $A$. cylindrocarpon seedlings.

\section{CONCLUSION}

It is advisable to restore $A$. cylindrocarpon seedlings in two height classes owing to the high survival rate, leaf appearance, and growth found in the present study. 
The no-leaf reduction treatment $(0 \%)$ is the most viable alternative for the production of $A$. cylindrocarpon seedlings, via rescue seedlings.

\section{ACKNOWLEDGMENTS}

To Universidade Federal dos Vales do Jequitinhonha e Mucuri (UFVJM) for financial support.

\section{REFERENCES}

CALEGARI, L. Seedling production of native tree species in nurseries via rescue of young plants Revista Árvore, v.35, p.41-50, 2011. Available from: <http://www.scielo.br/pdf/rarv/v35n1/05.pdf> Accessed: June. 20, 2014. doi: 10.1590/S0100-67622011000100005.

CARNEIRO, J.G.A. Produção e controle de qualidade de mudas florestais. Curitiba: UFPR, 1995. 451p.

CARVALHO, P.E.R. Espécies florestais brasileiras: recomendações silviculturais, potencialidades e uso da madeira. Colombo: EMBRAPA - CNPF, 1994. 640p.

CLINE, M.G. The role of hormones in apical dominance. New approaches to an old problem in plant development. Physiologia Plantarum, v.90, p.230-237, 1994. Available from: <http://onlinelibrary.wiley.com/ doi/10.1111/j.1399-3054.1994.tb02216.x/full>. Accessed Jun 10, 2014. doi: 10.1111/j.1399-3054.1994.tb02216.x.

FALK, D.A. et al. Restoring diversity: strategies for reintroduction of endangered plants. Washington: Island, 1996. 505p.

GOOD, J.E.G. et al. Translocation of herb-rich grassland from a site in Wales prior to opencast coal extraction. Restoration Ecology, v.7, p.337-347, 1999. Available from: <http://onlinelibrary.wiley.com/ doi/10.1046/j.1526-100X.1999.72028.x/abstract>. Accessed: Dec. 13, 2013. doi: 1 0.1046/j.1526-100X.1999.72028.x.

HARTMANN, H.T. et al. Plant propagation: principles and practices. 7.ed. New Jersey: Prentice Hall, 2002. 880p.

LAMB, D. et al. Restoration of degraded tropical Forest landscapes. Science, v.310, p.1628-1632, 2005. Available from: $<\mathrm{http}: / /$ science sciencemag.org/content/310/5754/1628.full >. Accessed: Dec 20, 2013. doi: $10.1126 /$ science. 1111773 .
LIMA, J.D. et al. Effects of luminosity on the growth seedlings of Caesalpinia ferrea Mart. ex Tul. (Leguminosae, Caesalpinoideae). Acta Amazônica, v.38, n.1, p.5-10, 2008. Available from: <http:// www.scielo.br/pdf/aa/v38n1/v38n1a02>. Accessed: Dec 20, 2013.

RAVEN, P.H. et al. Biologia vegetal. 7.ed. Rio de Janeiro: Guanabara Koogan, 2007. 728p.

SANTANA, R.C. et al. Influence of leaf area reduction on clonal production of Eucalyptus seedlings. Cerne, v.16, p.251-257, 2010. Available from: <http://www.scielo.br/ scielo.php?pid $=\mathrm{S} 010477602010000300001 \&$ script $=$ sci arttext\&tlng=pt $>$. Accessed: Nov 10, 2013. doi: 10.1590/S010477602010000300001 .

SOUZA, C.A.M. et al. Crescimento em campo de espécies florestais em diferentes condições de adubação. Ciência Florestal, v.16, p.243-249, 2006. Available from: <https://periodicos.ufsm. br/cienciaflorestal/article/view/1905>. Accessed: Dec 10, 2013. doi: 10.5902/198050981905

STATSOFT, INC. (2010). STATISTICA (data analysis software system), version 10. Available from: <www.statsoft.com $>$. Accessed: June 10, 2014

VIANI, R.A.G.; RODRIGUES, R.R. Sobrevivência em viveiro de mudas de espécies nativas retiradas da regeneração natural de remanescente florestal. Pesquisa Agropecuária Brasileira, v.42, p.1067-1075, 2007. Available from: <http:// www.scielo.br/scielo.php? script $=$ sci_arttext\&pid $=$ S 0100 204X2007000800002> Accessed: Nov 20, 2013. doi: 10.1590/ S0100-204X2007000800002.

VIDAL, C.Y. Transplante de plântulas e plantas jovens como estratégia de produção de mudas para a restauração de áreas degradadas. 2008. 162f. Dissertação (Mestrado em Conservação de Ecossistemas Florestais - Curso de Pós-graduação em Recursos Florestais, Universidade de São Paulo, Piracicaba, SP.

XAVIER, A.; WENDLING, I.; SILVA, R. L. Silvicultura clonal: princípios e técnicas. Viçosa, MG: UFV, 2009. 272p.

WENDELBERGER, K.S. et al. Rescue and restoration: experimental translocation of Amorpha herbacea Walter var. crenulata (Rybd.) Isley into a novel urban habitat. Restoration Ecology, v.16, p.542-552, 2008. Available from: <http://onlinelibrary.wiley.com/doi/10.1111/ j.1526-100X.2007.00325.x/pdf>. Accessed: June 10, 2014. 